\title{
STUDI KASUS PENGGUNAAN INTERNET YANG BERBASIS PANCASILA BAGI WARGA PERUM LOH AGUNG JATEN KARANGNAYAR
}

\author{
Dr. HANURING AYU A.P, SH, MH ${ }^{1}$
}

\begin{abstract}
ABSTRAK
Bagaimanakah pengaturan tentang penghinaan di dunia maya dalam hukum positif indonesia? Bagaimana etika menggunakan sosial media yang benar ? Bagaimana aplikasi etika menggunakan sosial media yang sesuai dengan pancasila. Metode pengabdian kepada masyarakat ini adalah berupa penyuluhan dalam bentuk ceramah dan diskusi , tanya jawab serta dilanjutkan dengan praktek demonstrasi penggunan etika yang baik dan benar dalam berselancar di dunia maya. Pelaksanaan kegiatan pengabdian ini dengan metode pendidikan kepada masyarakat (peternak) melalui penyuluhan, pelatihan, dan demontrasi di lapangan serta penerapan/aplikasi langsung (percontohan) dengan melibatkan kelompok ibu ibu di sekitar wilayah perumahan loh agung, jaten karanganyar. Tujuan gerakan internet sehat adalah untuk memberikan pendidikan kepada pengguna internet untuk menganalisis pesan yang disampaikan, mempertimbangkan tujuan komersil dan politik dibalik citra atau pesan di internet dan meneliti siapa yang bertanggungjawab atas pesan yang diimplikasikan itu. Bagaimanapun pelanggaran terhadap etika tersebut bisa berdampak kurang baik bahkan bisa menjadi sesuatu yang buruk bagi kita dan anak kita. Konsekuensinya sendiri bisa terjadi dalam bentuk ringan seperti pengucilan, pemblokiran, dan hal sejenis lainnya, hingga dalam bentuk yang cukup berat yang bisa membawa kita berurusan dengan pihak kepolisian dan pengadilan. Dari hasil pengabdian pada masyarakat dapat disimpulkan bahwa kegiatan pengabdian di perumahan loh agung jaten Kecamatan jaten Kabupaten karanganyar melalui penyuluhan hukum dapat memberi dampak positif ke warga masyarakat,berdasarakan nilai-nilai luhur yang terkandung dalam Pancasila.
\end{abstract}

Kata Kunci : internet, pancasila dan warga

${ }^{1}$ STAFF PENGAJAR FAKULTAS HUKUM UNIVERSITAS ISLAM BATIK SURAKARTA 


\title{
CASE STUDY OF THE USE OF THE INTERNET BASED ON PANCASILA FOR THE LOH AGUNG RESIDENT, JATEN KARANGNAYAR
}

\author{
Dr. HANURING AYU A.P, SH, $\mathrm{MH}^{2}$
}

\begin{abstract}
How is the setting of humiliation in cyberspace in Indonesian positive law? How is the right ethics in using social media? How is ethical application in using social media compatible with Pancasila? This community service method was in the form of counseling in the way of lectures and discussions, question and answer and continued by practicing demonstration of the use of good and true ethics in surfing in cyberspace. The implementation of this service was done through education method to the community with counseling, training, and demonstrating in field and direct application by involving group of mothers around the Loh Agung residential area Jaten Karanganyar. The goal of a healthy internet movement is to provide education to internet users, to analyze the messages conveyed, to consider commercial and political purposes behind images or messages on the internet and to examine who is responsible for the implied message. However, violations of such ethics may have an adverse effect and can even be a bad thing for us and our children. The consequences can occur in the form of ostracism, blocking, and other similar things. It also can bring severe consequence such as we have to deal with the police and the courts. The results concluded that the activities of dedication in Loh Agung Resident, Jaten Karanganyar regency through legal counseling can give a positive impact to the community, based on the noble values contained in Pancasila.
\end{abstract}

Keywords: internet, pancasila and citizens

${ }^{2}$ Lecturer at Faculty of Law, Islamic Batik University, SURAKARTA 


\section{PENDAHULUAN}

Indonesia merupakan

salah satu negara di dunia yang memiliki jumlah populasi penduduk terbanyak sehingga setiap perubahan maupun inovasi yang terjadi akan langsung masuk dan dirasakan oleh penduduknya termasuk dalam bidang teknologi. Bahkan dengan jumlah penduduk yang berkisari pada jumlah 200 juta orang, maka tak salah bila banyak orang menyebut Indonesia sebagai pasar yang sangat potensial untuk dunia digital. Oleh karena itu, menurut penelitian yang dilakukan, ada sekitar 88,1 juta orang yang menggunakan internet aktif di Indonesia sebagai media sosial mereka. Bisnis jasa media sosial pun semakin meraup untung apalagi Indonesia penduduknya sangat rajin mengakses internet. Jumlah itupun diperkirakan akan semakin bertambah setiap tahunnya. Fakta menarik lainnya yang bisa diliihat dari data pertumbuhan pengguna internet dan media sosial adalah penggunaan televisi kini semakin mengalami penurunan.

Dengan jumlah penduduk sekitar 200 juta, tak salah apabila Indonesia sering disebut sebagai pasar potensial digital. Sebab, sampai saat ini sudah ada sekitar 88,1 juta pengguna internet aktif di Indonesia. Jumlah itu pun diperkirakan dapat terus bertambah. Selain itu, fakta lain yang juga menarik adalah televisi di Indonesia mengalami penurunan rata-rata waktu tonton. Hal ini juga tak lepas dari pengguna internet di Indonesia yang lebih sering mengakses internet. Fakta-fakta tersebut merupakan salah satu data yang berhasil dihimpun dari pengguna internet di Indonesia.

Kementerian Komunikasi dan Informasi menyebutkan penggunaan internet mayoritas digunakan masyarakat untuk menikmati konten media sosial. Pengguna internet di Indonesia dari data paling banyak 
mengunakan media sosial, Semakin Indonesia melek dengan teknologi, maka pengguna internet di dalam negeri akan terus bertambah. Menurut data yang telah dikumpulkan oleh We Are Social, dalam setahun mulai dari 2015 hingga 2016, ada kenaikan sekitar $15 \%$ pengguna internet di Indonesia. Kenaikan ini lebih dikhususkan untuk mereka yang merupakan pengguna aktif media sosial. Kemungkinan di akhir 2016 mendatang, kenaikan masih akan terus berlanjut dan semakin signifikan.

Data ini masih terus bertambah dimana penggunaan media sosial melalui smartphone menjadi meningkat sebesar enam persen dari tahun sebelumnya. Itulah mengapa penggunaan gadget semakin meningkat dan pembelian gadget baru yang mumpuni dengan sistem media sosial yang diunduh pun juga meningkat. Sementara menurut APJII atau singkatan dari Asosiasi
Penyelenggara jasa Internet Indonesia mengatakan bahawa $48 \%$ dari 88,1 juta orang pengguna internet itu merupakan masyarakat pengonsumsi internet harian. Itu artinya, warga Indonesia tidak bisa lepas dari gadget dan internet untuk mengakses media sosial setiap harinya.

Bila jumlah pengguna internet di Indonesia semakin bertambah, maka waktu untuk akses internet juga akan semakin banyak dibandingkan dengan kegiatan lain termasuk nonton televisi. Untuk bisa mengakses internet dan media sosial melalui PC, ponsel maupun tablet dalam satu harinya, dibutuhkan waktu sekitar 4 jam 42 menit. Hasil ini semakin menggusur posisi televisi yang pada awalnya juga memiliki konsumsi lebih lama. Kini dalam satu harinya, penggunaan televisi hanya sekitar 2 jam 22 menit setiap harinya. Jumlah ini tentu tidak 
ada apa-apanya dengan internet yang mampu menguras waktu para pengguna. Apalagi semakin banyaknya jumlah aplikasi media sosial baru yang dikembangkan beserta keunikannya masingmasing, tak heran jika nantinya jumlah waktu ini akan semakin meningkat. Pengguna internet aktif memang berjumlah 88,1 juta orang dan 79 juta diantarannya menggunakan internet untuk media sosial.

Bila dilihat dari jumlah penduduk di Indonesia yang berjumlah 200 juta orang, ada sekitar 30 persen penduduk yang menjadi langganan setia untuk mengakses media sosial. Media sosial dapat berfungsi untuk membuat banyak orang merasa terhubung dengan orang lain dan memudahkan akses informasi. Hal ini kemudian dimanfaatkan sebagai salah satu media pemasaran yang efektif mengingat cakupan media sosial yang luas dan dilengkapi dengan filter sehingga dapat dipilih kepada siapa iklan kita ingin ditujukan. Sekarang pun semakin banyak orang yang menggunakan media sosial sebagai sarana promosi karena selain cakupannya luas, biayanya pun lebih murah dibandingkan dengan promosi secara konvensional. Itulah mengapa bisnis jasa media sosial semakin berkembang dengan baik dan semakin banyak orang berlomba-lomba menciptakan media sosial yang bisa menguntungkan di masa depan.

Sejatinya, jejaring sosial dan teknologi informasi memiliki tujuan untuk mempererat hubungan antarorang dan memperlancar komunikasi. Sayangnya, kerapkali seseorang menyalahgunakan esensi itu. Jejaring sosial digunakan untuk mengintimidasi, melecehkan, menghina, hingga mencemarkan nama baik orang lain secara verbal melalui media SMS, surel, 
dan internet. Inilah yang disebut cyber bullying.

Pencemaran nama atau penghinaan baik lewat sosial media telah menjadi fenomena yang marak terjadi di jejaring sosial dalam beberapa tahun belakangan ini. Pencemaran nama baik merupakan perbuatan melawan hukum yang menyerang kehormatan atau nama baik orang lain. Pencemaran nama baik melalui jaringan internet dalam perkembangannya sudah dapat di kategorikan sebagai kejahatan yang mengkawatirkan.

Kasus-kasus penghinaan melalui jejaring sosial yang berujung pemidanaan banyak bermunculan. Undang-Undang Informasi dan Transaksi Elektronik (UU ITE) menjadi jerat hukum yang ampuh untuk membuat siapa pun bisa bermalam di tahanan. Dalam konteks tersebut, dibutuhkan keseimbangan antara penegakan hukum dan sebuah titik kapan kebebasan berekspresi layak dijunjung.

Secara

umum pencemaran nama baik adalah tindakan mencermarkan nama baik seseorang dengan cara menyatakan sesuatu baik melaui lisan ataupun tulisan. pencemaran nama baik terbagi kedalam beberapa bagian :

1) Secara lisan, yaitu pencemaran nama baik yang diucapkan

2) Secara tertulis, yaitu pencemaran yang dilakukan melalui tulisan

Dalam pencemaran nama baik, terdapat 3 catatan penting didalamnya, yakni : Pertama, delik dalam pencemaran nama baik merupakan delik yang bersifat subyektif yang artinya penilaian terhadap pencemaran sangat bergantung pada pihak yang diserang nama baiknya. Oleh karenanya, delik dalam pencemaran merupakan delik aduan yang hanya bisa diproses oleh pihak yang berwenang jika 
ada pengaduan dari korban pencemaran.

Kedua, pencemaran nama baik merupakan delik penyebaran. Artinya, substansi yang berisi pencemaran disebarluaskan kepada umum atau dilakukan di depan umum oleh pelaku.

Ketiga, orang yang melakukan pencemaran nama baik dengan menuduh suatu hal yang dianggap menyerang nama baik seseorang atau pihak lain harus diberi kesempatan untuk membuktikan tuduhan itu.

Bagi bangsa indonesia, pasal pencemaran nama baik dianggap sesuai dengan karakter bangsa ini yang menjunjung tinggi adat dan budaya timur, pencemaran nama baik dianggap melanggar norma sopan santun bahkan bisa melanggar norma agama jika yang dituduhkan mengandung unsur fitnah.

\section{Pencemaran nama}

baik sangat erat kaitannya dangan suatu kata penghinaan dimana penghinaan itu sendiri memiliki pengertian perbuatan menyerang nama baik dan kehormatan seseorang. Sasaran dalam pencemaran nama baik pun dapat digolongkan menjadi :

a) Terhadap pribadi perorangan

b) Terhadap kelompok atau golongan

c) Terhadap suatu agama

d) Terhadap orang yang sudah meninggal e) Terhadap para pejabat yang meliputi pegawai negeri, kepala negara atau wakilnya

Berdasarkan kondisi tersebut diatas, maka akan dilaksanakan pengabdian masyarakat tentang etika berselancar di dunia maya bagi warga desa jaten perumahan loh agung, jaten, karanganyar. 


\section{A. IDENTIFIKASI}

DAN

PERUMUSAN MASALAH

1. Bagaimanakah pengaturan tentang penghinaan di dunia maya dalam hukum positif indonesia?

2. Bagaimana etika menggunakan sosial media yang benar?

3. Bagaimana aplikasi etika menggunakan sosial media yang sesuai dengan pancasila

\section{B. TUJUAN KEGIATAN}

1. Untuk mengetahui dan menganalisis tentang pengaturan tentang pengaturan tentang tindak pidana penghinaan lewat dunia maya di dalam hukum positif Indonesia.

2. Untuk memahami etika berselancar di dunia maya

3. Untuk mengetahui menggunakan sosial media berdasarkan pada nilai nilai pancasila

\section{MANFAAT KEGIATAN}

1. Bagi masyarakat desa jaten, kecamatan jaten sosialisasi tentang etika berselancar di dunia maya akan menambah wawasan dan pengetahuan untuk lebih berhati hati dalam menggunakan sosial media

2. Untuk mengetahui etika menggunakan media sosial berdasarkan dengan nilai nilai pancasila

3. Bagi Uniba, para dosen dapat membagi ilmunya kepada masyarakat dalam melaksanakan tri darma perguruan tinggi

\section{METODE PELAKSANAAN}

Metode pengabdian kepada masyarakat ini adalah berupa penyuluhan dalam bentuk ceramah dan diskusi, tanya jawab serta dilanjutkan dengan praktek demonstrasi penggunan etika yang baik dan benar dalam berselancar di dunia maya. Pelaksanaan kegiatan pengabdian ini dengan metode pendidikan kepada masyarakat 
(peternak) melalui penyuluhan, pelatihan, dan demontrasi di lapangan serta penerapan/aplikasi langsung (percontohan) dengan melibatkan kelompok ibu ibu di sekitar wilayah perumahan loh agung, jaten karanganyar.

Penyuluhan dilakukan diperumahan loh agung, Desa jaten Kecamatan jaten, kabupaten karanganyar untuk menambah wawasan dan pengetahuan serta pemahaman warga sekitar perumahan loh agung khususnya para ibu ibu tentang konsepsi dunia maya. Materi penyuluhan dilengkapi dengan beberapa contoh.

Pelatihan dan demontrasi cara cara yang baik dan benar dalam menggunakan sosial media, internet, di dunia maya. Pelatihan ini diberikan kepada warga sekitar perumahan loh agung jaten, dalam rangka penerapan Pengabdian sehingga warga sekitar perumahan loh agung bisa memahami etika ketika berselancar di dunia maya.
Aplikasi dilapangan dilakukan setelah warga mendapatkan penyuluhan dan mengikuti pelatihan dan demontrasi sehingga warga betul-betul mengerti, paham mengenai etika berselancar di dunia maya.

\section{E. HASIL DAN PEMBAHASAN}

Pemahaman dan bijak ketika menggunakan internet dan sosial media dan ketika berselancar di dunia maya meningkat dibandingkan dengan sebelum dilaksanakannya kegiatan pengabdian kepada masyarakat adalah salah satu faktor untuk terus melaksanakan kegiatan pengabdian di lokasi yang sama.

Meningkatnya pemahaman dan pengertian tentan etika berselancar di dunia maya membawa dampak positif bagi para warga sekitar perumahan loh agung jaten karena dengan adanya peningkatan pemahaman ini membuat para warga menjadi lebih bijak ketika berselancar di dunia maya. 
Permasalahan warga masyarakat sekitar perumahan loh agung jaten adalah masih minimnya pemahaman tentang etika berselancar di dunia maya. Masih kurangnya perhatian terhadap penggunaan dunia maya bagi masyarakat sehingga membuat warga masyarakat seringkali membuat postingan dan seringkali membaca konten yang isinya negatif atau pun yang bersifat hoax.

Hoax adalah usaha untuk menipu atau mengakali pembaca/pendengarnya untuk mempercayai sesuatu, padahal sang pencipta berita palsu tersebut tahu bahwa berita tersebut adalah palsu. Salah satu contoh pemberitaan palsu yang paling umum adalah mengklaim sesuatu barang atau kejadian dengan suatu sebutan yang berbeda dengan barang/kejadian sejatinya. Suatu pemberitaan palsu berbeda dengan misalnya pertunjukan sulap; dalam pemberitaan palsu, pendengar/penonton tidak sadar sedang dibohongi, sedangkan pada suatu pertunjukan sulap, penonton justru mengharapkan supaya ditipu (Wikipedia, n.d.).

Berdasarkan persoalan masyarakat tersebut, dengan penerapan pengabdian pada masyarakat berbasis teknologi ini dengan memberikan dampak positif ke warga masyarakat dengan meningkatnya kepahaman mengenai etika berselancar di dunia maya. Hal ini telah dapat dilaksanakan dengan penerapan hasil pengabdian kepada warga masyarakat dalam transfer pengetahuan dan keterampilan serta penguasaan teknologi tentang pemahaman etika ketika menggunakan internet dan sosial media di dunia maya.

Pancasila sebagai Dasar Negara Republik Indonesia

Pancasila dipergunakan sebagai dasar mengatur pemerintahan negara atau mengatur penyelenggaraan negara. Pengertian Pancasila sebagai dasar negara sesuai dengan bunyi 
pembukaan UUD 1945, yang menyatakan: “...maka disusunlah kemerdekaan kebangsaan Indonesia itu dalam suatu UUD Negara Indonesia, yang berbentuk dalam suatu susunan negara Indonesia yang berkedaulatan rakyat dengan berdasar kepada...". Pancasila mempunyai kedudukan istimewa dalam hidup kenegaraan dan hukum bangsa Indonesia. Fungsi pokok Pancasila adalah sebagai dasar negara, sesuai dengan pembukaan UUD 1945, sebagai sumber dari segala sumber hukum atau sumber dari tertib hukum, sebagaimana tertuang dalam Ketetapan MPRS No.XX/MPRS/1966. Pengertian demikian adalah pengertian Pancasila yang bersifat yuridis ketatanegaraan.

Pancasila merupakan dasar negara Indonesia yang dibentuk oleh para pendiri bangsa Indonesia. Sebagai dasar negara, Pancasila mengandung nilai-nilai yang sejatinya sudah ada dalam bangsa Indonesia sendiri. Sehingga Pancasila mampu menjadi wadah bagi masyarakat Indonesia yang beragam. Pancasila sebagai dasar negara tidak dapat dirubah ke dalam bentuk suatu apapun. Mau tidak mau, Pancasila adalah dasar negara yang mempunyai kedudukan istimewa dalam hidup kenegaraan dan dan hukum bangsa Indonesia.

Arti dan Makna Sila Kemanusiaan yang Adil dan Beradab

Menurut perumusan Dewan Perancang Nasional, perikemanusiaan adalah daya serta karya budi dan hati nurani manusia untuk membangun dan membentuk kesatuan diantara manusia sesamanya, tidak terbatas pada manusia-sesamanya yang terdekat saja, melainkan juga seluruh umat manusia. Sedangkan menurut Bung Karno istilah perikemanusiaan adalah hasil dari pertumbuhan rohani, kebudayaan, hasil pertumbuhan dari alam tingkat rena ke taraf yang lebih tinggi.

Pokok pikiran dari sila Kemanusiaan yang Adil dan Beradab : 
1. Menempatkan

manusia sesuai

dengan hakikatnya

sebagai makhluk

Tuhan. Maksudnya,

kemanusiaan itu

universal.

2. Menjunjung tinggi

kemerdekaan

sebagai hak segala

bangsa.

Menghargai hak

setiap warga dan

menolak

rasialisme.

3. Mewujudkan

keadilan dan

peradaban yang

tidak lemah.

Hakikat manusia memiliki unsurunsur yang diantaranya adalah susunan kodrat manusia (yang terdiri atas raga dan jiwa), sifat kodrat manusia (yang terdiri atas makhluk social dan individu), kedudukan kodrat manusia (yang terdiri atas makhluk berdiri sendiri dan makhluk Tuhan).
Butir-butir Pancasila Sila ke-Dua

Sila ke-dua Pancasila ini mengandung makna warga Negara Indonesia mengakui adanya manusia yang bermartabat (bermartabat adalah manusia yang memiliki kedudukan, dan derajat yang lebih tiinggi dan harus dipertahankan dengan kehidupan yang layak), memperlakukan manusia secara adil dan beradab di mana manusia memiliki daya cipta, rasa, karsa, niat dan keinginan sehingga jelas adanya perbedaan antara manusia dan hewan.

Jadi sila kedua ini menghendaki warga Negara untuk menghormati kedudukan setiap manusia dengan kelebihan dan kekurangan masingmasing, setiap manusia berhak mempunyai kehidupan yang layak dan bertindak jujur serta menggunakan norma sopan santun dalam pergaulan sesama manusia. Butir-butir sila ke-dua adalah sebagai berikut:

1. Mengakui persamaan derajat, persamaan hak 
dan kewajiban antar sesama manusia.

2. Saling mencintai sesama manusia.

3. Mengembangkan sikap tenggang rasa.

4. Tidak bersikap semenamena terhadap orang lain.

5. Menjunjung tinggi nilai kemanusiaan.

6. Gemar melakukan kegiatan kemanusiaan.

7. Berani membela kebenaran dan keadilan.

8. Merasa dirinya sebagai bagian dari seluruh umat manusia, karena itu perlu mengembangkan sikap saling menghormati dan bekerjasama dengan bangsa lain.

Makna dari sila ini diharapkan dapat mendorong seseorang untuk senantiasa menghormati harkat dan martabat oranglain sebagai pribadi dan anggota masyarakat. Dengan sikap ini diharapkan dapat menyadarkan bahwa dirinya merupakan makhluk sosial yang mempunyai hak dan kewajiban yang sama.

Atas dasar sikap perikemanusiaan ini, maka bangsa Indonesia menghormati hak hidup bangsa lain menurut aspirasinya masingmasing. Dan menolak segala bentuk penjajahan di muka bumi ini. Hal itu dikarenakan berlawanan dengan nilai perikemanusiaan.

Implementasi Sile ke-Dua dalam Kehidupan Masyarakat

Sesuai dengan butir-butir sila ke-dua yang telah diuraikan pada pembahasan diatas, sila perikemanusiaan ini memiliki makna yang sangat berarti sebagai landasan kehidupan manusia. Sila ini dijadikan sebagai pedoman bertingkah laku dalam masyarakat. Selain itu peri kemanusiaan adalah naluri manusia yang berkembang sejak lahir. Sama halnya dengan naluri manusia yang lain, seperti naluri suka berkumpul, naluri berkeluarga, dan lain-lain. Oleh karena peri kemanusiaan merupakan naluri, maka tidak 
mungkin manusia

menghapuskannya. Dengan

perasaan peri kemanusiaan itulah

manusia dapat membentuk

masyarakat yang penuh kasih

sayang serta saling menghormati

diantara anggota-anggotanya.

Oleh karena itu tepatlah rumusan sila kemanusiaan yang adil dan beradab masuk dalam falsafah Pancasila. Nilai-nilai budaya yang terkandung dalam sila ini membentuk watak bangsa kita menjadi bangsa yang lemah lembut, sopan santun, tengang rasa, saling mencintai, bergotong royong dalam kebaikan, dan lain sebagainya.

Sehubungan dengan hal tersebut maka pengamalannya adalah sebagai berikut:

1. Mengakui persamaan derajat, persamaan hak, dan persamaan kewajiban antara sesama manusia. Butir ini menghendaki bahwa setiap manusia mempunyai martabat, sehingga tidak boleh

melecehkan manusia yang lain, atau menghalangi manusia lain untuk hidup secara layak, serta menghormati kepunyaan atau milik (harta, sifat dan karakter) orang lain.

2. Saling mencintai sesama manusia. Kata cinta menghendaki adanya suatu keinginan yang sangat besar untuk memperoleh sesuatu dan rasa untuk memiliki dan kalau perlu pengorbanan untuk

mempertahankannya.

Dengan perasaan cinta pula manusia dapat mempergiat hubungan social seperti kerjasama, gotong royong, dan solidaritas. Dengan rasa cinta kasih itu pula orang akan berbuat ikhlas, saling membesarkan hati, saling berlaku setia dan jujur, saling menghargai 
harkat dan derajat satu sama lain.

3. Mengembangkan sikap tenggang rasa. Sikap ini menghendaki adanya usaha dan kemauan dari setiap manusia Indonesia untuk menghargai dan menghormati perasaan orang lain. Harusnya dalam bertingkah laku baik lisan maupun perbuatan kepada orang lain, hendaknya diukur dengan diri kita sendiri; bilamana kita tidak senang disakiti hatinya, maka janganlah kita menyakiti orang lain.

Sikap tenggang rasa juga dapat kita wujudkan dalam toleransi dalam beragama.

4. Tidak semena-mena terhadap orang lain. Semena-mena berarti sewenang-wenang, berat sebelah, dan tidak berimbang. Oleh sebab itu butir ini menghendaki, perilaku setiap manusia terhadap orang tidak boleh sewenang-wenang, harus menjunjung tinggi hak dan kewajiban.

5. Menjunjung tinggi nilai kemanusiaan. Setiap warga Negara harus menjunjung tinggi dan melaksanakan nilai-nilai kemanusiaan dengan baik, seperti:

$$
\begin{aligned}
& \text { a. Mengakui adanya } \\
& \text { masyarakat yang } \\
& \text { bersifat majemuk }
\end{aligned}
$$

b. Melakukan musyawarah dengan dasar kesadaran dan kedewasaan untuk menerima kompromi

c. Melakukan sesuatu dengan pertimbangan moral dan ketentuan agama

d. Melakukan sesuatu dengan jujur dan kompetisi yang sehat 
e. Memerhatikan kehidupan yang layak antar sesama

f. Melakukan kerja sama dengan iktikad baik dan tidak curang

Dengan memperhatikan nilai-nilai pancasila yang ada maka dibawah ini adalah etika-etika dalam menggunakan internet yaitu sebagai berikut:

1. Jangan menyindir, menghina, melecehkan, atau menyerang pribadi seseorang/pihak lain.

2. Jangan sombong, angkuh, sok tahu, sok hebat, merasa paling benar, egois, berkata kasar, kotor, dan hal-hal buruk lainnya yang tidak bisa diterima orang.

3. Menulis sesuai dengan aturan penulisan baku. Artinya jangan menulis dengan huruf kapital semua (karena akan dianggap sebagai ekspresi marah), atau penuh dengan singkatan-singkatan tidak biasa dimana orang lain mungkin tidak mengerti maksudnya (bisa menimbulkan salah pengertian).

4. Jangan mengekspose hal-hal yang bersifat pribadi, keluarga, dan sejenisnya yang bisa membuka peluang orang tidak bertanggung jawab memanfaatkan hal itu.

5. Perlakukan pesan pribadi yang diterima dengan tanggapan yang bersifat pribadi juga, jangan ekspose di forum.

6. Jangan turut menyebarkan suatu berita/informasi yang sekiranya tidak logis dan belum pasti kebenarannya, karena bisa jadi berita/informasi itu adalah berita bohong (hoax). Selain akan mempermalukan diri sendiri orang lainpun bisa tertipu dengan berita/info itu bila ternyata hanya sebuah hoax.

7. Andai mau menyampaikan saran/kritik, lakukan dengan personal message, jangan lakukan di depan forum karena hal tersebut bisa membuat tersinggung atau rendah diri orang yang dikritik. 
8. Selalu memperhatikan Hak Atas Kekayaan Intelektual (HAKI). Artinya jangan terlibat dalam aktivitas pencurian/penyebaran data dan informasi yang memiliki hak cipta.

9. Jika mengutip suatu tulisan, gambar, atau apapun yang bisa/diijinkan untuk dipublikasikan ulang, selalu tuliskan sumber aslinya.

10. Jangan pernah memberikan nomor telepon, alamat email, atau informasi yang bersifat pribadi lainnya milik teman kepada pihak lain tanpa persetujuan teman itu sendri.

Alhamdulillah setelah penerapan program pengabdian pada masyarakat warga masyarakat loh agung jaten dapat lebih bijak menggunakan sosial media dan internet di dunia maya. Jadi etika dalam menggunakan Internet sangat penting sekali bagi semua pengguna internet, etika yang dimaksudkan disini adalah dalam forum-forum yang bersifat umum dimana banyak orang/pihak tidak dikenal yang terlibat. Jika hanya berinteraski dengan teman sendiri yang sudah akrab, mungkin ini tidak jadi masalah mengingat si temanpun pasti sudah hafal karakter masingmasing, tetapi tentu saja tetap harus ada batas-batas yang tidak boleh dilampaui.

Munculnya gerakan literasi media khususnya internet sehat merupakan salah satu wujud kepedulian terhadap dampak buruk media internet. Perkembangan internet selain memberikan dampak positif pada kehidupan manusia juga memiliki dampak negatif. Beberapa dampak negatif tersebut diantaranya adalah mengurangi tingkat privasi individu, dapat meningkatkan kecenderungan potensi kriminal, dapat menyebabkan overload-nya informasi, dan masih banyak lagi (Sholihuddin, n.d.).

Tujuan gerakan internet sehat adalah untuk memberikan pendidikan kepada pengguna internet untuk menganalisis pesan yang disampaikan, 
mempertimbangkan tujuan komersil dan politik dibalik citra atau pesan di internet dan meneliti siapa yang bertanggungjawab atas pesan yang diimplikasikan itu. Oleh karena itu, agar gerakan internet sehat dapat berjalan secara optimal maka sangat diperlukan pendidikan berinternet salah satunya adalah pendidikan etika berinternet. Pendidikan internet lebih pada pembelajaran tentang etika bermedia internet, bukan pengajaran melalui media. Pendidikan etika bermedia internet bertujuan untuk mengembangkan baik pemahaman kritis maupun partisipasi aktif, sehingga anak muda sebagai konsumen media internet memiliki kemampuan dalam membuat membuat tafsiran dan penilaian berdasarkan informasi yang diperolehnya. Selain itu anak muda mampu menjadi produser media internet dengan caranya sendiri sehingga menjadi partisipan yang berdaya di komunitasnya (Setiawan, 2012).

\begin{tabular}{lll} 
Pentingnya & Etika & Dalam \\
\hline menggunakan & Internet & adalah
\end{tabular}

sebagai berikut:

1. Bahwa pengguna internet berasal dari berbagai negara yang mungkin memiliki budaya, bahasa dan adat istiadat yang berbedabeda.

2. Pengguna internet merupakan orang-orang yang hidup dalam dunia anonymouse, yang tidak mengharuskan pernyataan identitas asli dalam berinteraksi.

3. Berbagai macam fasilitas yang diberikan dalam internet memungkinkan seseorang untuk bertindak etis seperti misalnya ada juga penghuni yang suka iseng dengan melakukan hal-hal yang tidak seharusnya dilakukan.

4. Harus diperhatikan bahwa pengguna internet akan selalu bertambah setiap saat dan memungkinkan

masuknya penghuni baru didunia maya tersebut. 
Sebenarnya masih banyak hal yang perlu diperhatikan sebagai bagian dari etika menggunakan internet. Akan tetapi yang menjadi intinya adalah walaupun internet ini dunia maya, akan tetapi karena interaksi yang terjadi di dalamnya tetap melibatkan manusia dengan berbagai jenis dan karakter tak ubahnya di dunia nyata sehari-hari, maka etika keseharian tetap harus diterapkan. Bagaimanapun pelanggaran terhadap etika tersebut bisa berdampak kurang baik bahkan bisa menjadi sesuatu yang buruk bagi kita dan anak kita. Konsekuensinya sendiri bisa terjadi dalam bentuk ringan seperti pengucilan, pemblokiran, dan hal sejenis lainnya, hingga dalam bentuk yang cukup berat yang bisa membawa kita berurusan dengan pihak kepolisian dan pengadilan.

\section{SIMPULAN}

Dari hasil pengabdian pada masyarakat dapat disimpulkan bahwa kegiatan pengabdian di perumahan loh agung jaten
Kecamatan jaten Kabupaten karanganyar melalui penyuluhan hukum dapat memberi dampak positif ke warga masyarakat,berdasarakan nilai-nilai luhur yang terkandung dalam Pancasila maka yang pertama, Meningkatkan pemahaman etika berselancar di dunia maya dengan memperhatikan asas-asas dalam Pancasila, kedua meningkatkan pemahaman mengenai postingan dan kontent yang tidak benar. Yang ketiga Semakin besarnya jumlah penguna internet dan dengan mudahnya mendapatkan informasi saat ini menjadikan berita hoax semakin dengan mudah tersebar. Yang keempat, Biasanya budayabudaya pada negara yang sudah melek internet/media sosial membuat berita hoax semakin mudah tersebar.

\section{DAFTAR PUSTAKA}

Darji Darmo Diharjo, dkk.1991.Santiaji 
Pancasila.Surabaya:Usana Offset

Printing.hal.16-20.

Atut saksono. 2007. Pancasila

Soekarno. Yogyakarta: CV Urna

Cipta Media Jaya. Hal 40.

Soekarno. 1964. Tjamkan

Pantjasila. Djakarta:- hal 121.

Rukiyati, dkk. 2008. Pendidikan

Pancasila. Yogyakarta: UNY Press.

Hal 67-68.

Drs. Kaelan. 1993. Filsafat

Pancasila.Yogyakarta: Paradigma.

Hal 104.

Herman, dkk. 1986. Panorama Jiwa

dan Kepribadian Bangsa

PANCASILA. Jakarta: CV Indrajaya.

Hal 94.

Prof.H.Muzayin, 1990. Ideologi

Pancasila. Jakarta: Golden Terayon

Press. Hal 38-39.

Sri Janti,dkk. 2008. Etika berwarga

Negara. Jakarta: Salemba Empat.

Hal 26-28. 